Annals of Plant and Soil Research 23(2): 186-191 (2021)

https://doi.org/10.47815/apsr.2021.10054

\title{
Effect of wrapping and packaging materials on fruit rot of guava (Psidium guajava Linn.)
}

\section{GYANA NAND JHA AND H.K. CHOURASIA*}

\author{
Applied Microbiology and Plant Pathology Laboratory, University Department of Botany, T.M. Bhagalpur \\ University, Bhagalpur-812 007, Bihar (India)
}

Received: February, 2021; Revised accepted: April, 2021

\begin{abstract}
In the present study, wrapping and packaging materials were evaluated for their capacity to decrease the decay losses of guava fruits during storage under ambient conditions $\left(18-22^{\circ} \mathrm{C}\right.$ and $\left.75-80 \% \mathrm{RH}\right)$ at Tej Narayan Banaili College, T.M. Bhagalpur University, Bhagalpur during the year 2014-2016. Results revealed that post-harvest decay loss can be minimized significantly through proper wrapping or packaging of fruits for storage. Fruits wrapped with heat-shrinkable low density polyethylene film (LDPE, $25 \mu \mathrm{m}$ thick), or packed up to 30 days of storage in corrugated fibre board (CFB) boxes exhibited low decay losses of 11.9 and 22.8 per cent, respectively. In general, the fruit loss due to fungal attack increased with increasing duration of storage. Altogether 7 fungal species were found associated with rotten fruits during the storge. Botryodiplodia theobromae, was the most prominent post-harvest rotting agent causing $37.5 \%$ fruit loss. Colletotrichum gloeosporioides, Pestalotia psidii and Alternaria alternata showed 30.8, 25.5 and 16.8\% fruit decay losses, respectively. Aspergillus niger (10.6\%) Penicillium expansum (7.0\%) and Rhizopus stolonifer (4.5\%) caused least per cent decay losses of guava fruits.
\end{abstract}

Key words: Wrapping, packaging, fruit rot, guava

\section{INTRODUCTION}

Guava (Psidium guajava Linn.) is an arborescent shrub or a small tree and is one of the popular fruits of north India. It is a very productive and profitable fruit crop occupies 25.66 million hectares with an annual production of 320.48 million tones (National Horticulture Board, 2020). During the last two decades fruit production was adversely affected by postharvest rots caused by Aspergillus niger Van Tiegh., Colletotrichum gloeosporioides Penz., Pestalotia psidii Pat. and Penicillium expansum Link (Ray et al., 2007 Srivastava and Lal, 2009, 2010; Chourasia and Jha, 2010). These pathogens not only blemish, disfigure or cause rots to fruits but post-infectional biochemical changes also reduce their food and market value considerably (Jha, 2017).

Despite major constraint caused by fruit rot pathogens, considerable quantity (25-30\%) of guava fruits get spoil during transit and storage. It has also been estimated by the FAO (2018) that the post harvest loss of perishable commodities in India is as high as $30 \%$. This high loss has been attributed to several factors among which lack of wrapping, packaging, storage facilities and poor means of transportation are the major ones. The postharvest losses could discourage farmers from producing and marketing fresh produce and limit the urban consumption of fresh fruits and vegetables. Hence, development of post-harvest technologies is believed to make great contribution to improve quality and use of these crops. These procedures include maintaining optimal relative humidity to reduce water loss without accelerating decay, adding chemical preservatives to reduce physiological and microbial losses, and maintaining an optimal gaseous environment to slow respiration and senescence (Awole et al., 2011; Tigist et al., 2011). Packaging fruits is one of the most commonly used post-harvest practice that puts them into unitized volumes which are easy to handle while also protecting them from hazards of transportation and storage (Burdon, 2011). Modified atmosphere packaging for storage and transportation of fruits and vegetables is commonly achieved by packing them in plastic films. Storage in plastic films with different kinds of combinations of materials, perforation and inclusion of chemicals and individual seal packaging are types of modified atmosphere storage (Irtwange, 2006). 
Various fungicides have shown promising results in controlling the post-harvest rotting of guava fruits (Srivastava and Kumar, 2006). In view of the development of fungicidal resistant isolates of post-harvest rot pathogens (Ishii, 2006) and the possible mammalian toxicity of the more effective fungicides (Deising et al., 2018), alternative methods to control fruit loss due to fungal decay during the storage are urgently needed. The post-harvest life of fruits can be increased without involving fungitoxicants by cooling and controlled atmosphere storage (Singh and Rao, 2005). But both of these technologies are expensive and furthermore, storage below $5^{\circ} \mathrm{C}$ may cause chilling injury in guava fruits. So it is not possible to readily adopt these technologies. In the present study, an attempt has been made to study the effect of different wrapping and packaging materials on the post-harvest fruit rot of guava during storage under ambient conditions.

\section{MATERIALS AND METHODS}

Healthy and mature guava fruits of nearly equal size and without any visible injury were harvested in the first week of December for two consecutive years (2014-15 and 2015-16). Fruits were washed with chlorinated $(0.02 \%)$ water and then air dried under shade. These fruits were further used for wrapping and packaging to evaluate suitable streategy to minimize decay during storage.

\section{Wrapping}

The fruits were wrapped with news paper, butter paper, perforated polythene bags (100 guage) and heat-shrinkable low density polyethylene film (LDPE, $25 \mu \mathrm{m}$ thick) within 24 $\mathrm{hr}$ of harvest. The fruits without any wrapping served as control. These fruits were packed in corrugated fibre board (CFB) boxes. Each box contained 50 fruits as one replication. Each of five treatments was replicated three times. The fruits were stored under ambient conditions (18$22^{\circ} \mathrm{C}$ temp. and $\left.75-80 \% \mathrm{RH}\right)$. The data regarding fruit decay were recorded at 10 days intervals upto 30 days of storage and per cent fruit decay loss was worked out (Singh and Thakur, 2003). The data of cumulative fruit decay for 2 years were pooled and analysed statistically after angular transformation. The decay reduction index (DRI) was calculated as per cent.

$\mathrm{DRI}=\frac{\text { Decay in control }- \text { Decay in treatment }}{\text { Decay in control }} \times 100$

Packaging

The fruit were packed in different packaging materials viz. corrugated fibre board boxes, wooden boxes, polythene bags (8-10 pin holes) and jute bags within $24 \mathrm{hr}$ of harvest. Paper shreds were used as cushioning materials in order to avoid bruising during handling of fruits. The fruits packed in jute bags were considered as control because this practice is widely used by local farmers. Each of four treatments was replicated thrice with 50 fruits in each replication. The fruits were stored under ambient conditions (18- $22^{\circ} \mathrm{c}$ temp. and $75-80 \%$ $\mathrm{RH})$. The data regarding fruit decay were recorded, calculated and analysed as described under wrapping above.

Isolation of mycoflora associated with decayed fruits

Decayed fruits observed during storage were separated from healthy ones. The isolation of associated causal agents was done on potato dextrose agar (PDA) medium and subsequently purified by single spore isolation technique. Pathogenicity of each isolated mycoflora was tested by following Koch's postulates. Per cent incidence of mycoflora associated with decayed fruits was worked out on the basis of total decayed fruits observed during storage for two years consecutively.

\section{RESULTS AND DISCUSSION}

\section{Effect of wrapping materials on the decay loss}

The pooled data (Table 1) revealed that fruits wrapped with different wrappers exhibited significantly less decay loss in comparison to unwrapped fruits. The least decay was observed in fruits wrapped with heat-shrinkable low density polyethylene film (LDPE, 25 $\mu \mathrm{m}$ thick). News paper and butter paper were the next in order of superiority. Wrapping with perforated polyethylene bags proved to be the least effective. The decay incidence showed progressive increase with increasing period of 
storage. There was significant difference among the loss estimate on 10 days, 20 days and 30 days of storage. These findings are in agreement with those of Sharma et al. (2008) who found that heat-shrinkable film reduced post-harvest decay loss in kinnow (Citrus deliciosa) fruits. The reduction in loss might be due to complete sealing of fruits that prevents the spread of rotting as well as the transfer of spores and debris from fruit to fruit in the same container (Rana and Siddiqui, 2018). Contrary to this, fruits packed in perforated polyethylene bags exhibited a higher per cent decay loss, possibly due to higher humidity maintained inside bags.

Table 1. Effect of wrapping materials on fungal decay loss of guava fruits during storage

\begin{tabular}{|c|c|c|c|c|c|c|c|c|c|c|}
\hline \multirow{2}{*}{ Wrappers } & \multicolumn{3}{|c|}{ 2014-15 } & \multicolumn{3}{|c|}{$015-16$} & \multicolumn{3}{|c|}{ Pooled (mean) } & \multirow{2}{*}{$\begin{array}{c}\text { Decay reduction } \\
\text { index }\end{array}$} \\
\hline & $10 \mathrm{~d}$ & $20 d$ & $30 d$ & $10 d$ & $20 d$ & $30 d$ & $10 \mathrm{~d}$ & $20 d$ & $30 d$ & \\
\hline Newspaper & $\begin{array}{l}12.7 \\
(5.4)\end{array}$ & $\begin{array}{c}19.5 \\
(11.9)\end{array}$ & $\begin{array}{c}24.7 \\
(19.5)\end{array}$ & $\begin{array}{l}10.5 \\
(4.9)\end{array}$ & $\begin{array}{c}17.7 \\
(11.2)\end{array}$ & $\begin{array}{c}24.5 \\
(18.8)\end{array}$ & $\begin{array}{l}11.6 \\
(5.2)\end{array}$ & $\begin{array}{c}18.6 \\
(11.6)\end{array}$ & $\begin{array}{c}24.6 \\
(19.2)\end{array}$ & 34.5 \\
\hline ButterPaper & $\begin{array}{l}12.7 \\
(5.4)\end{array}$ & $\begin{array}{l}19.5 \\
(11.9)\end{array}$ & $\begin{array}{l}25.8 \\
(22.5)\end{array}$ & $\begin{array}{l}11.2 \\
(5.1)\end{array}$ & $\begin{array}{l}18.5 \\
(11.2)\end{array}$ & $\begin{array}{c}25.5 \\
(18.5)\end{array}$ & $\begin{array}{l}11.98 \\
(5.3)\end{array}$ & $\begin{array}{l}19.0 \\
(11.6)\end{array}$ & $\begin{array}{l}25.7 \\
(20.5)\end{array}$ & 31.6 \\
\hline PPB & $\begin{array}{l}15.5 \\
(6.5)\end{array}$ & $\begin{array}{c}21.7 \\
(13.8)\end{array}$ & $\begin{array}{l}20.8 \\
(24.9)\end{array}$ & $\begin{array}{l}13.7 \\
(5.8)\end{array}$ & $\begin{array}{l}20.5 \\
(12.7)\end{array}$ & $\begin{array}{c}25.5 \\
(19.7)\end{array}$ & $\begin{array}{l}14.6 \\
(6.2)\end{array}$ & $\begin{array}{c}21.1 \\
(13.3)\end{array}$ & $\begin{array}{l}27.4 \\
(22.3)\end{array}$ & 16.1 \\
\hline HSPF & $\begin{array}{l}0.7 \\
(0.0)\end{array}$ & $\begin{array}{l}14.5 \\
(5.9)\end{array}$ & $\begin{array}{l}20.8 \\
(12.2)\end{array}$ & $\begin{array}{l}0.6 \\
(0.0)\end{array}$ & $\begin{array}{l}13.5 \\
(4.8)\end{array}$ & $\begin{array}{c}18.5 \\
(11.6)\end{array}$ & $\begin{array}{c}0.6 \\
(0.0)\end{array}$ & $\begin{array}{l}14.0 \\
(5.3)\end{array}$ & $\begin{array}{r}19.6 \\
(11.9)\end{array}$ & 70.2 \\
\hline Control & $\begin{array}{l}14.5 \\
(6.6)\end{array}$ & $\begin{array}{c}22.9 \\
(14.7)\end{array}$ & $\begin{array}{l}29.5 \\
(25.5)\end{array}$ & $\begin{array}{l}15.0 \\
(6.7)\end{array}$ & $\begin{array}{c}21.8 \\
(14.9) \\
\mathrm{CD}(\mathrm{P}=\end{array}$ & $\begin{array}{c}28.6 \\
(24.8) \\
.05)\end{array}$ & $\begin{array}{l}14.7 \\
(6.6)\end{array}$ & $\begin{array}{c}22.4 \\
(14.8)\end{array}$ & $\begin{array}{l}29.0 \\
(25.2)\end{array}$ & 0.0 \\
\hline Wrappers & & 1.7 & & & 1.6 & & & 1.2 & & \\
\hline Days & & 1.3 & & & 1.0 & & & 0.9 & & \\
\hline Interaction & & 2.6 & & & 2.1 & & & 1.8 & & \\
\hline CV (\%) & & 7.9 & & & 7.3 & & & 5.5 & & \\
\hline
\end{tabular}

Figures were arcsine transformed before analysis; actual \% decay loss in parenthesis

$P P B=$ Perforated polythene bag, $H S P F=H e a t$ shrinkable polyethylene film

The least decay in guava fruits when wrapped with LDPE film might be due to increasing shelf life of fruits by retardation of ripening and senescence processes partially through reducations of $\mathrm{O}_{2}$ and increase of $\mathrm{CO}_{2}$ concentrations in the packaging head space (Irtwange, 2006). Low $\mathrm{O}_{2}$ and high $\mathrm{CO}_{2}$ in the head space reduce respiration and the production of ethylene during storage in passive MAP, which in turn reduces physiological and chemical changes responsible for the fruits quality deterioration (Ntsoane and Mahajan, 2020).

\section{Effect of packaging materials on the decay loss}

There was a significant effect of packaging materials on fruit decay up to 30 days of storage (Table 2). The least loss due to fungal decay was noticed when the fruits were packed in wooden boxes and CFB boxes. Fruits packed in jute bags, which served as control, exhibited the highest damage due to fungal attack as recorded also in polyethylene bags. The extent of fruit loss due to fungal decay increased as the period of storage increased. Earlier, Lu et al. (2010) have reported that post-harvest rotting of apple fruits can he minimized significantly by fruit packing in wooden boxes and CFB boxes. The present result is also in corroboration with the observation made by Azene et al. (2014) on papaya fruits. The differences in rotting in different packages might be attributed to the presence of fungal propagules on the pack surface and variation in moisture content in the surrounding atmosphere of the fruits (Chandra et al., 2018). The higher decay loss in jute bags and polythene bags were possibly because of more bruising during the handling of fruits (Nath et al., 2012; Hussein et al., 2015) and moreover, the chances of contamination of jute bags would also be more. Fruit loss due to fungal decay increased with increasing period of storage. It might be due to the weakening of defence system of the fruits against fungal attack because of decrease in pectin substances during storage resulting in decreased firmness (Sharma et al., 2008). Alternatively existing fungal propagules multiplied and increased over the period of storage. 
Table 2. Effect of packaging materials on the fungal decay loss of guava fruits during storage

\begin{tabular}{|c|c|c|c|c|c|c|c|c|c|c|}
\hline \multirow{2}{*}{ Packaging materials } & \multicolumn{3}{|c|}{$2014-15$} & \multicolumn{3}{|c|}{$2015-16$} & \multicolumn{3}{|c|}{ Pooled (mean) } & \multirow{2}{*}{$\begin{array}{l}\text { Decay reduction } \\
\text { index }\end{array}$} \\
\hline & $10 \mathrm{~d}$ & $20 d$ & $30 \mathrm{~d}$ & $10 \mathrm{~d}$ & $20 d$ & $30 d$ & $10 d$ & $20 d$ & $30 \mathrm{~d}$ & \\
\hline Wooden boxes & $\begin{array}{l}14.5 \\
(6.7)\end{array}$ & $\begin{array}{c}22.3 \\
(14.2)\end{array}$ & $\begin{array}{c}31.7 \\
(24.1)\end{array}$ & $\begin{array}{l}15.0 \\
(6.8)\end{array}$ & $\begin{array}{c}22.6 \\
(14.3)\end{array}$ & $\begin{array}{c}31.5 \\
(24.0)\end{array}$ & $\begin{array}{l}14.8 \\
(6.7)\end{array}$ & $\begin{array}{c}22.4 \\
(14.2)\end{array}$ & $\begin{array}{c}31.6 \\
(24.0)\end{array}$ & 25.2 \\
\hline Polythene bags & $\begin{array}{l}16.2 \\
(9.5)\end{array}$ & $\begin{array}{c}25.6 \\
(17.5)\end{array}$ & $\begin{array}{l}33.5 \\
(30.1)\end{array}$ & $\begin{array}{l}17.0 \\
(9.7)\end{array}$ & $\begin{array}{c}25.9 \\
(17.6)\end{array}$ & $\begin{array}{c}34.6 \\
(30.5)\end{array}$ & $\begin{array}{l}16.6 \\
(9.6)\end{array}$ & $\begin{array}{c}25.8 \\
(17.5)\end{array}$ & $\begin{array}{c}34.0 \\
(30.3)\end{array}$ & 13.3 \\
\hline CFB boxes & $\begin{array}{l}14.4 \\
(8.7)\end{array}$ & $\begin{array}{c}22.5 \\
(15.0)\end{array}$ & $\begin{array}{c}29.2 \\
(23.1)\end{array}$ & $\begin{array}{l}14.8 \\
(8.7)\end{array}$ & $\begin{array}{c}26.2 \\
(16.3)\end{array}$ & $\begin{array}{c}28.4 \\
(22.5)\end{array}$ & $\begin{array}{l}14.6 \\
(8.7)\end{array}$ & $\begin{array}{c}24.3 \\
(15.6)\end{array}$ & $\begin{array}{c}28.3 \\
(22.8)\end{array}$ & 27.1 \\
\hline Control & $\begin{array}{c}16.5 \\
(10.7)\end{array}$ & $\begin{array}{c}26.3 \\
(16.5)\end{array}$ & $\begin{array}{c}38.7 \\
(35.5) \\
\operatorname{CD}(\mathrm{F}\end{array}$ & $\begin{aligned} & 17.2 \\
&(11.1) \\
&=0.05)\end{aligned}$ & $\begin{array}{c}27.5 \\
(17.2)\end{array}$ & $\begin{array}{l}36.5 \\
(33.3)\end{array}$ & $\begin{array}{c}16.8 \\
(10.9)\end{array}$ & $\begin{array}{c}26.9 \\
(16.8)\end{array}$ & $\begin{array}{c}37.6 \\
(34.4)\end{array}$ & 0.0 \\
\hline PN & & 1.5 & & & 1.4 & & & 1.2 & & \\
\hline Days & & 1.0 & & & 1.8 & & & 1.6 & & \\
\hline Interaction & & 2.4 & & & 2.1 & & & 1.8 & & \\
\hline CV (\%) & & 5.3 & & & 4.8 & & & 4.5 & & \\
\hline
\end{tabular}

Figures were arcsine transformed before analysis; actual \% decay loss in parenthesis, PM=Packaging materials

Influence of mycoflora associated with postharvest decay

Seven fungal species viz, Alternaria alternata, Aspergillus niger, Botryodiplodia theobromae, Colletotrichum gloeosporioides, Penicillium expansum, Pestalotia psidii and Rhizopus stolonifer were isolated from decayed guava fruits during storage (Table 3 ). Among these A.alternata, B.theobromae, C.gloeosporioides and P.psidii were the most predominantly associated with more than $60 \%$ of the total fruit loss due to fungal decay. Of these four dominant fungi highest decay loss of $37.5 \%$ was caused due to B. theobromae followed by C. gloeosporioides (30.8\%), P. psidii (25.5\%) and least deterioration was recorded in case of A. alternata (16.8\%). Aspergillus niger, $P$. expansum and $R$. stolonifer exhibited moderate $(10.6 \%)$, poor $(7.0 \%)$ and rare $(4.5 \%)$ occurrence on fruits during storage upto 30 days. The present result is in corroboration with observation made by Singh et al. (2008).

Table 3. Association of mycoflora with decayed fruits of guava during storage

\begin{tabular}{|c|c|c|c|}
\hline \multirow{2}{*}{ Mycoflora } & 2014-15 & 2015-16 & \multirow{2}{*}{$\begin{array}{l}\text { Pooled (mean) } \\
\text { decay loss }(\%)\end{array}$} \\
\hline & $\%$ decay loss & $\%$ decay loss & \\
\hline Alternaria alternata & 15.7 & 17.8 & 16.8 \\
\hline Aspergillus niger & 11.5 & 9.7 & 10.6 \\
\hline Botryodiplodia theobromae & 38.6 & 36.4 & 37.5 \\
\hline Colletotrichum gloeosporioides & 29.7 & 31.8 & 30.8 \\
\hline Penicillium expansum & 6.5 & 7.5 & 7.0 \\
\hline Pestalotia psidii & 27.0 & 24.1 & 25.5 \\
\hline Rhizopus stolonifer & 5.8 & 3.2 & 4.5 \\
\hline$C D(P=0.05)$ & 1.5 & 1.7 & 1.3 \\
\hline CV (\%) & 4.7 & 5.2 & 4.4 \\
\hline
\end{tabular}

${ }^{*}$ Figures were arcsine transformed before analysis

The pathogenic variability in causing fruit decay loss among the fungal isolates is might be due to variation in their production potential of pectolytic and cellulolytic enzymes which involves the degradation of cell wall constituents, especially pectic substance and cellulose of the host (Prusky et al., 2013). They reported that the culture filtrates of these organisms contain a number of pectic enzymes which are capable of tissue maceration by degrading the pectic substances of the host. The exact mechanism by which host cells are killed by these fungal pathogens in not clearly understood. However, Singh et al. (2008) are also of the view that both killing and maceration are accomplished by pectic enzymes. It is difficult to visualize how 
pectic enzymes alone can act as poisonous material for living protoplasm. Possibly, these enzymes make the host cells accessible to toxic molecules that do not enter the intact cells freely. Yet the other possibility is that the cells are killed before the enzymes act.

From the aforesaid results, it could be concluded that post-harvest fruit decay losss due

\section{REFERENCES}

Awole, S., Kebede, W. and Workneh, T.S. (2011) Post-harvest quality and shelf-life of some hot pepper varieties. Journal of Food Science and Technology 10 : 1007-1011.

Azene, M., Workneh, T.S. and Woldetsadik, K. (2014.) Effect of packaging materials and storage environment on postharvest quality of papaya. Journal of Food Science Technology 51 : 10411055.

Burdon, J.N. (2011) Post-harvest handling of tropical and substropical fruit for export. In : Mitra, S. (ed) post-harvest physiology and storage of tropical and subtropical fruits. Faculty of Horticulture, CAB International, West Bengal, India, pp. 1-19.

Chandra, D., Lee, J.S., Choi, H.J. and Kim, J.G. (2018) Effect of packaging on shelf life and post-harvest qualities of radish roots during storage at low temperature for an extended period. Journal of Food Quality 10 : 1155-1165.

Chourasia, H.K. and Jha, G.N. (2010) Fruit rot diseases of guava and physiochemical changes in fruits under pathogenesis. Journal of Mycology and Plant Pathology 40 : 432-435.

Deising, H.B., Reimann, S. and Pascholati, S.F. (2018) Mechanisms and significance of fungicide resistance. Brazilian Journal of Microbiology 39: 286-295.

F.A.O. (2018) Tapes about statistics of food crops. Food and Agriculture Organizations of the United Nations, Rome, Italy.

Hussein, Z., Caleb, O.J. and Opara, U.L. (2015) Perforation-mediated modified atmosphere packaging of fresh and minimally processed produce - a review. Food Packaging and Shelf Life 6 : 7-20. to fungal attack can be significantly minimized by wrapping of guava fruits with heat-shrinkable low density polyethylene film (LDPE, $25 \mu \mathrm{m}$ thick) and by packaging in CFB boxes during the storage at ambient conditions up to a period of 30 days.

Irtwange, S.V. (2006) Application of modified atmosphere packaging and related technology in post-harvest handling of fresh fruits and vegetables. Agricultural Engineering International 4 : 1-12

Ishii, H. (2006) Impact of fungicide resistance in plant pathogens on crop disease control and agricultural environment. Japan Agricultural Research Quarterly 40 : 205-211

Jha, G.N. (2017) Studies on fruit rot diseases of guava of Bihar and its management. Ph.D Thesis, T.M. Bhagalpur University, Bhagalpur.

Lu, F., Ishikawa, Y., Kitazawa, H. and Sataka, T. (2010) Impact damage to apple fruits in commercial corrugated fiberboard box packaging evaluated by the pressure sensitive film technique. Journal of Food Agriculture Environment 8 : 281-222.

Nath, A., Deka, B.C. and Singh, A. (2012) Extention of shelf life of pear fruits using different packaging materials. Journal of Food Science and Technology 49 : 556563.

National Horticulture Board (2020) Area and production of horticulture crops for 201920. Ministry of Agriculture and Farmers Welfare, Government of India.

Ntsoane, M.L. and Mahajan, P.V. (2020) Optimization of $\mathrm{O}_{2}$ and $\mathrm{CO}_{2}$ concentrations to retain quality and prolong shelflife of mango fruit using a simplex lattice mixture design. Biosystems Engineering 192 : 14-23.

Prusky, D., Alkan, N., Mengiste, T. and Fluhr, R. (2013) Quiescent and necrotrophic lifestyle choice during post-harvest disease development. Annual Review Phytopathology $51: 55-76$.

Rana, S. and Siddiqui, S. (2018) Comparative effect of different individual wrappings 
on shelf life of guava (Psidium guajava). Journal of Food Science and Technology 55 : 2935-2944

Ray, S.K., Jana, M., Maity, S.S., Bhattacharya, R. and Khatua, D.C. (2007) Fruit diseases of guava in West Bangal. Acta Horticulture 73 : 525-531.

Sharma, R.N., Maharshi, R.P. and Gaur, R.B. (2008) Etticacy of waxing, wrapping and packaging material in reducing postharvest decay loss of kinnow (Citrus deliciosa) fruits. Journal of Mycology and Plant Pathology 38 : 546-550.

Singh, A., Verma, K.S. and Mohan, C. (2008) Prevalence of anthracnose of guava in Punjab and its management. Journal of Mycology and Plant Pathology 38 : 245248.

Singh, D. and Thakur, A.K. (2003) Effect of packaging on quality and rotting of kinnow fruits during storage. Haryana Journal of Horticultural Science 32 : 191-196.

Singh, S.P. and Rao, D.V. (2005) Effect of modified atmosphere packaging on alleviation of chilling injury and dietary antioxidants levels in papaya during low temperature storage. European Journal of Horticultural Sceince 70 : 246-252.

Srivastava, R. and Lal, A.A. (2009) Incidence of post-harvest fungal pathogens in guava and banana in Allahabad. Journal of Horticultural Science 4 : 85-89.

Srivastava, R. and Lal, A.A. (2010) Effect of biocontrol agents Candida albicans and Debarymyces hansenii on shelf-life of fruits of guava (Psidium guajava). Journal of Mycology and Plant Pathology 40 : 269-271.

Srivastava, R.P. and Kumar, S. (2006) Principles and practices of fruit and vegetables preservation, $3^{\text {rd }} \mathrm{Ed} \quad \mathrm{pp}$ 1-11, International Book Distributing Co, Lucknow, U.P. India.

Tigist, M., Workneh, T.S. and Woldetsadik, K. (2011) Effects of variety on the quality of tomato stored under ambient conditions. Journal of Food Science and Technology 10 : 1013-1018. 